\title{
References
}

1. Kuper, D.J., Spiker, D.G. and Coble, P.A. et al. Sleep and treatment prediction in endogenous depression Am. J. Psychiatry, 1981, 138, 4, 429-434.

2. Dressing, H., Reimann, D. and Gann, H. et al. The value of sleep variables as prognostic markers of antidepressive treatment. Biol. Psychiat. 1991, 29, 11S, 302-303.

3. Borbely, A.A. The $S$ deficiency hypothesis of depression and two process model of sleep regulation. Pharmacopsychiatr. 1987, $20,23-29$.

4. Chen, C.N., Sleep, depression and antidepressants. Brit. J. Psychiat. 1979, 135, 385-402.

\section{Nefazodone vs amitriptyline in major depressive inpatients}

Ansseau, M., Cerfontaine, J.L., Darimont, P., de Nayer, A., Devoitille, J.M., Dierick, M., Evrard, J.L., Gérard, M.A., Kremer, P.J., Lecoq, A., Mertens, C., Mesotten, F., Troisfontaines, B., van Moffaert, $M$. and Vanbrabant, $E$. Psychiatric Unit, C.H.U. du Sart Tilman, B-4000 Liège, Belgium

Key words: Nefazodone; Amitriptyline; Antidepressant; Major depression

Nefazodone, a potent 5HT2 antagonist, down-regulates both $\beta$-adrenergic and 5HT2 receptors in the frontal cortex when given chronically (Eison et al., 1990). Flexible doses of nefazodone $(100-400 \mathrm{mg} / \mathrm{d})$ and amitriptyline $(50-200 \mathrm{mg} / \mathrm{d})$ were compared in 103 major depressive inpatients in a 6-week double-blind study. Results showed significant superiority of amitriptyline over nefazodone on all rating instruments: MADRS $(P<0.01$ from week 2$)$, Hamilton depression scale $(p<0.01$ from week 4$)$, and CGI ( $<0.01$ from week 4$)$. Complementary analyses showed that the treatment differences were the largest for the 33 melancholic patients who had used tricyclics in the past whereas it was clinically nil for the 26 nonmelancholic patients who never experienced tricyclics. $65 \%$ of patients under amitriptyline and $56 \%$ of patients under nefazodone reported adverse events during the study, with more dry mouth in the amitriptyline group (39\% vs $11 \%$ ). Mean final daily doses reached $242 \mathrm{mg}$ with nefazodone and $124 \mathrm{mg}$ with amitriptyline. These findings, which contradict results in US patients (D'Amico et al., 1990), should be discussed with regard to the dose of nefazodone, probably too low for melancholic patients and to the clinical differences between the patient samples (Ansseau, 1992).

\section{References}

Ansseau, M. (1992). The Atlantic gap: clinical trials in Europe and the U.S.A. (Editorial). Biol. Psychiatry 31, $109-111$.

D'Amico, M.F., Roberts, D.L., Robinson, D.S., Schwiderski, U.E. and Copp, J. (1990). Placebo-controlled dose-ranging trial designs in phase II development of nefazodone. Psychopharmacol. Bull. 26 (1), 147-150.

Eison, A.S., Eison, M.S., Torrente, J.R., Wright, R.N. and Yocca, F.D. (1990). Nefazodone: Preclinical pharmacology of a new antidepressant. Psychopharmacol. Bull. 26 (3), 311-315. 